\title{
SYNTHESIS OF FLAVANONE-6-CARBOXYLIC ACID DERIVATIVES FROM SALICYLIC ACID DERIVATIVE
}

\author{
Muhammad Idham Darussalam Mardjan", Retno Ambarwati, Sabirin Matsjeh, \\ Tutik Dwi Wahyuningsih, and Winarto Haryadi
}

Department of Chemistry, Faculty of Mathematics and Natural Sciences, Universitas Gadjah Mada, Sekip Utara, Yogyakarta, Indonesia, 55281

Received November 9, 2011; Accepted December 21, 2011

\begin{abstract}
Synthesis of flavanone-6-carboxylic acid derivatives had been conducted via the route of chalcone. The synthesis was carried out from salicylic acid derivative, i.e. 4-hydroxybenzoic acid, via esterification, Fries rearrangement, Claisen-Schmidt condensation and 1,4-nucleophilic addition reactions. Structure elucidation of products was performed using FT-IR, ${ }^{1} \mathrm{H}-\mathrm{NMR}, \mathrm{GC}-\mathrm{MS}$ and UV-Vis spectrometers. Reaction of 4-hydroxybenzoic acid with methanol catalyzed with sulfuric acid produced methyl 4-hydroxybenzoate in $87 \%$ yield. The acidcatalyzed-acetylation of the product using acetic anhydride gave methyl 4-acetoxybenzoate in $75 \%$ yield. Furthermore, solvent-free Fries rearrangement of methyl 4-acetoxybenzoate in the presence of $\mathrm{AlCl}_{3}$ produced 3acetyl-4-hydroxybenzoic acid as the acetophenone derivatives in 67\% yield. Then, Claisen-Schmidt condensation of the acetophenone and benzaldehyde derivatives of p-anisaldehyde and veratraldehyde in basic condition gave 2'hydroxychalcone-5'-carboxylic acid derivatives in 81 and $71 \%$ yield, respectively. Finally, the ring closure reaction of the chalcone yielded the corresponding flavanone-6-carboxylic acids in 67 and 59\% yield, respectively.
\end{abstract}

Keywords: Flavanone-6-carboxylic acid; Fries rearrangement; Claisen-Schmidt condensation; 1,4-nucleophilic addition

\section{ABSTRAK}

Sintesis turunan flavanon-6-asam karboksilat melalui senyawa antara kalkon telah dilakukan. Sintesis dilakukan dari bahan dasar asam 4-hidroksibenzoat melalui reaksi esterifikasi, penataan ulang Fries, kondensasi Claisen-Schmidt and adisi 1,4-nukleofilik. Elusidasi struktur dari produk dilakukan menggunakan spektrometer IR, ${ }^{1} \mathrm{H}$-NMR, GC-MS dan UV-Vis. Reaksi asam 4-hidroksibenzoat dengan metanol terkatalisis asam sulfat menghasilkan metil 4-hidroksibenzoat (87\%). Asetilasi terkatalisis asam terhadap produk esterifikasi menggunakan asam asetat anhidrida menghasilkan metil 4-asetoksibenzoat (75\% yield). Selanjutnya, penataan ulang Fries metil 4-asetoksibenzoat dengan katalis $\mathrm{AlCl}_{3}$ menghasilkan turunan asetofenon berupa asam 3-asetil-4-hidroksibenzoat (67\%). Kondensasi Claisen-Schmidt antara turunan asetofenon dan turunan benzaldehida berupa p-anisaldehida dan veratraldehida menghasilkan turunan 2'-hidroksikalkon-5'-asam karboksilat dengan persen hasil sebesar 81 dan $71 \%$, berturut-turut. Reaksi penutupan cincin terhadap turunan kalkon menghasilkan isomer flavanonnya dalam 67 dan $59 \%$ hasil, berturut-turut.

Kata Kunci: flavanon-6-asam karboksilat; penataan ulang Fries; kondensasi Claisen-Schmidt; adisi 1,4-nukleofilik

\section{INTRODUCTION}

Flavanone, a class of flavonoids, has gained increasing attention due to its application in various aspects especially in healthy aspect. This compound had been applied as an anti-metastatis of lung cancer cells [1], an anti-cancer, an anti-oxidant, an antiinflammatory, an anti-fungal, an anti-bacteria [2-3] as well as an aromatase inhibitory [4]. In addition, intake of flavanone-contained-fruits is believed to reduce risk of

* Corresponding author. Tel/Fax : +62-8152011092

Email address : dham7sky@yahoo.com certain chronic diseases, such as cancer, and increase survival [5-6].

The flavanone, which is isomeric of 2'hydroxychalcones, is obtained from the latter through either acid- or basic-catalyzed-ring closure [3,7-8]. According to retrosynthetic analysis, the chalcone can be synthesized via Claisen-Schmidt condensation between o-hydroxy acetophenone and benzaldehyde [3]. The acetophenone can be produced via Fries rearrangement of phenyl ester in the presence of $\mathrm{AlCl}_{3}$ catalyst. Previous researchers used synthetic phenolic

Muhammad Idham Darussalam Mardjan et al. 


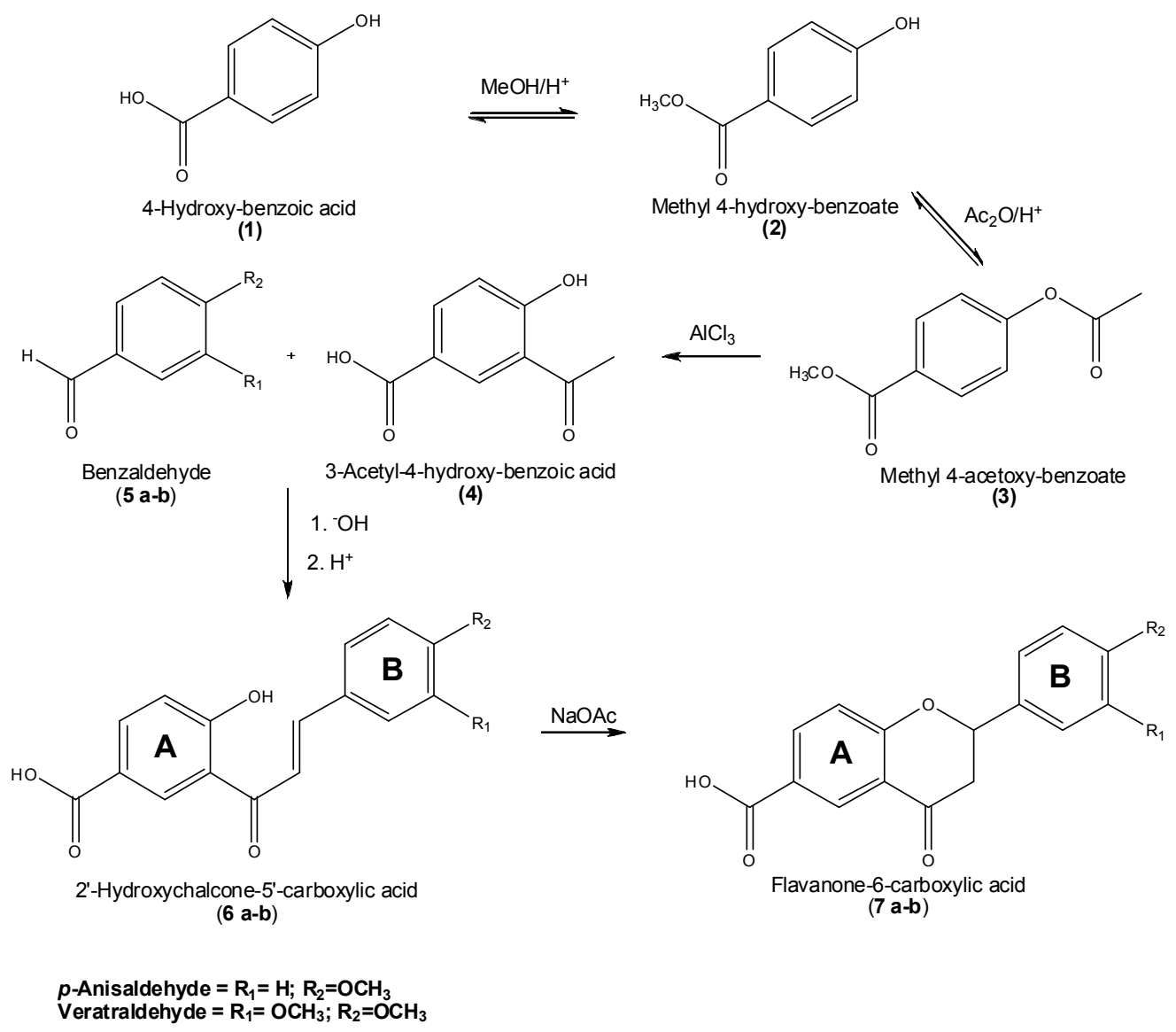

Fig 1. Route of synthesis of flavanone-6-carboxylic acid derivatives

compounds like phenol, recorcinol and phloroglucinol as raw materials to give the acetophenone [9]. On the other hand, the synthesis of the flavanone from natural products or their derivatives was rarely performed.

In the previous work, flavanone-6-carboxylic acid had already been synthesized from salicylic acid derivative and benzaldehyde [10]. In this research, the acetophenone derivative 4 (from wintergreen oil) and the benzaldehydes of $p$-anisaldehyde 5 a (from fennel oil [11]) and veratraldehyde $\mathbf{5 b}$ (from clove leave oil [12]) were employed in the synthesis of other flavanone-6carboxylic acid derivatives (Fig. 1).

\section{EXPERIMENTAL SECTION}

\section{Materials}

4-Hydroxybenzoic acid, acetic anhydride (Parker), potassium chloride $(\mathrm{KCl})$, aluminum chloride anhydrous $\left(\mathrm{AlCl}_{3}\right), p$-anisaldehyde, veratraldehyde sodium acetate $\left(\mathrm{CH}_{3} \mathrm{COONa}\right)$, sodium hydrogen carbonate $\left(\mathrm{NaHCO}_{3}\right)$, sodium sulfate anhydrous $\left(\mathrm{Na}_{2} \mathrm{SO}_{4}\right)$, potassium hydroxide $(\mathrm{KOH})$, hydrochloric acid $(\mathrm{HCl} 37 \%)$, sulfuric acid $\left(\mathrm{H}_{2} \mathrm{SO}_{4}\right.$ 98\%), methanol, ethanol, chloroform, dichloromethane and tetrahydrofuran (THF). All other chemicals, except acetic anhydride, were purchased from E. Merck.

\section{Instrumentation}

Laboratory glassware, Buchi evaporator R-124, melting-point apparatus (Electrothermal 9100), UVVisible spectrometer (UV-Vis, Spectronic-Array), infrared spectrometer (IR, Shimadzu-Prestige 21), proton nuclear magnetic resonance spectrometer $\left({ }^{1} \mathrm{H}\right.$ NMR, JEOL JNM-MY60) and gas chromatographymass spectrometer (GC-MS, Shimadzu QP-20105) were used in this work.

\section{Procedure}

\section{Synthesis of methyl 4-hydroxybenzoate}

Into $100 \mathrm{~mL}$ three-necked flask equipped with water condenser, $20 \mathrm{~mL}(500 \mathrm{mmol})$ of methanol was added into $7 \mathrm{~g}(50 \mathrm{mmol})$ of 4-hydroxy-benzoic acid 1 and followed by the addition of $4 \mathrm{~mL}$ of concentrated sulfuric acid. The mixture was refluxed for $5 \mathrm{~h}$ and allowed to cool to room temperature. The excess of 
methanol was then distilled off by rotary evaporator and the residue was dissolved in chloroform. The extract chloroform was washed with water and solution of $5 \%$ $\mathrm{NaHCO}_{3}$, dried with $\mathrm{Na}_{2} \mathrm{SO}_{4}$ and evaporated. Structure elucidation of the residue was performed with Infrared, ${ }^{1} \mathrm{H}-\mathrm{NMR}$ and GC-MS spectrometers.

\section{Synthesis of methyl 4-acetoxybenzoate}

As much as $3 \mathrm{~g}(20 \mathrm{mmol})$ of methyl 4hydroxybenzoate 2 and $6 \mathrm{~mL}(64 \mathrm{mmol})$ of acetic acid anhydride were placed in $100 \mathrm{~mL}$ three-necked flask and stirred well. Next, 10 drops of concentrated sulfuric acid was added into the mixture and the mixture was heated at $65^{\circ} \mathrm{C}$ for $2 \mathrm{~h}$. After cooling, the mixture was placed in ice bath until the crystallization occurred. Some cool aquadest might be added in order to decrease the solubility of the product. The solid was collected by vacuum filtration with Büchner funnel and then purified via recrystallization using hot ethanol : water (1:1). The product's structure was elucidated with Infrared, ${ }^{1} \mathrm{H}-\mathrm{NMR}$ and GC-MS spectrometers.

\section{Solvent-free Fries rearrangement of methyl 4- acetoxybenzoate}

In $100 \mathrm{~mL}$ three-necked flask equipped with water condenser and gas absorber, methyl 4-acetoxybenzoate $3(1.08 \mathrm{~g}, 5.6 \mathrm{mmol}), \mathrm{AlCl}_{3}(2.34 \mathrm{~g}, 17.5 \mathrm{mmol} \mathrm{mol})$ and $\mathrm{KCl}\left(0.64 \mathrm{~g}, 5 \mathrm{mmol}\right.$ ) were heated at $155-160{ }^{\circ} \mathrm{C}$ (oil bath temperature) for $1 \mathrm{~h}$. After cooling in an ice bath, the reaction mixture was digested with $22 \mathrm{~mL}$ of $\mathrm{HCl} 2$ $\mathrm{M}$. As much as $4.4 \mathrm{~mL}$ methanol was then added and the resulting suspension was refluxed at $60{ }^{\circ} \mathrm{C}$ for $0.5 \mathrm{~h}$. The crude product was filtered using Büchner funnel and recrystallized with ethanol. Structure elucidation of the product was performed with Infrared, ${ }^{1} \mathrm{H}-\mathrm{NMR}$ and GCMS spectrometers.

\section{General Procedures for obtaining chalcone-5'- carboxylic acid and flavanone-6-carboxylic acid derivatives}

Chalcone-5'-carboxylic acid derivatives. To an icedcooled solution of 3-acetyl-4-hydroxybenzoic acid 4 (2.78 $\mathrm{mmol})$ and benzaldehyde derivatives 5a-b (3 $\mathrm{mmol})$ in ethanol $(7.5 \mathrm{~mL})$, was added $\mathrm{KOH} 40 \%(2.5$ $\mathrm{mL}$ ). The solution was stirred at room temperature for 1 day. Thereafter, the excess of $\mathrm{HCl} 6 \mathrm{M}$ was poured into the reaction mixture, the resulting precipitate was filtered off, washed with aquadest and dried. The product was finally recrystallized from hot ethanol. The produced chalcone 6a-b was elucidated with infrared, ${ }^{1} \mathrm{H}-\mathrm{NMR}$ and UV-Visible spectrometers.

6a: Molecular formula: $\mathrm{C}_{17} \mathrm{H}_{14} \mathrm{O}_{5}$; yield: $81 \%$; M.P. : 224$226{ }^{\circ} \mathrm{C}$; IR (KBr): $3400(\mathrm{OH}), 1688$ (carbonyl acid), 1635 (carbonyl ketone), 1612 (conjugated double bond) and 1573 (aromatic) $\mathrm{cm}^{-1} ;{ }^{1} \mathrm{H}-\mathrm{NMR}$ (DMSO $\mathrm{D}_{6}, 60 \mathrm{MHz}$ ): $\delta$ $8.4\left(\mathrm{~d}, 1 \mathrm{H}, \mathrm{H}_{\beta}\right), 8.3\left(\mathrm{~d}, 1 \mathrm{H}, \mathrm{H}_{\alpha}\right), 7-8(\mathrm{~d}, 6 \mathrm{H}, \mathrm{Ar}-\mathrm{H}), 4.3(\mathrm{~s}$, $\left.3 \mathrm{H}, \mathrm{OCH}_{3}\right)$ and $4(\mathrm{~s}, 1 \mathrm{H}, \mathrm{OH})$; UV-Vis $(\mathrm{EtOH}): 368$ (band 1) and 245 (band II) nm.

6b: Molecular formula: $\mathrm{C}_{18} \mathrm{H}_{16} \mathrm{O}_{6}$; yield: $71 \%$; M.P. : 226-228 ${ }^{\circ} \mathrm{C}$; IR (KBr): $3400(\mathrm{OH}), 1689$ (carbonyl acid), 1635 (carbonyl ketone), 1612 (conjugated double bond) and 1574 (aromatic) $\mathrm{cm}^{-1}$; ${ }^{1} \mathrm{H}-\mathrm{NMR}$ (DMSO $\mathrm{D}_{6}$, $60 \mathrm{MHz}): \delta 8.3\left(\mathrm{~d}, 1 \mathrm{H}, \mathrm{H}_{\beta}\right), 8.1\left(\mathrm{~d}, 1 \mathrm{H}, \mathrm{H}_{\alpha}\right), 7-8(\mathrm{~d}, 7 \mathrm{H}$, Ar-H), $4.3\left(\mathrm{~s}, 6 \mathrm{H}, \mathrm{OCH}_{3}\right)$ and $3.9(\mathrm{~s}, 1 \mathrm{H}, \mathrm{OH})$; UV-Vis (EtOH): 383(band 1) and 247 (band II) $\mathrm{nm}$.

Flavanone-6-carboxylic acid derivatives. As much as $(1.04 \mathrm{mmol})$ of the chalcone derivative $\mathbf{6 a - b}$ was placed into three-necked-flask containing NaOAc (6.09 $\mathrm{mmol})$, water $(25 \mathrm{~mL})$ and ethanol $(5 \mathrm{~mL})$. The mixture was then refluxed for $24 \mathrm{~h}$. The cool reaction mixture was extracted with dichloromethane. Structure elucidation of the product $7 \mathbf{a}-\mathbf{b}$ was performed by means of infrared, ${ }^{1} \mathrm{H}-\mathrm{NMR}$ and UV-Visible spectrometers.

7a: Molecular formula: $\mathrm{C}_{17} \mathrm{H}_{14} \mathrm{O}_{5}$; yield: $67 \%$; M.P. : 209-211 ${ }^{\circ} \mathrm{C}$; IR (KBr): 1689 (carbonyl acid), 1604 (carbonyl ketone) and 1573 (aromatic) $\mathrm{cm}^{-1}$; ${ }^{1} \mathrm{H}-\mathrm{NMR}$ (DMSO $\left.\mathrm{D}_{6}, 60 \mathrm{MHz}\right): 6.7-8(\mathrm{~d}, 7 \mathrm{H}, \mathrm{Ar}-\mathrm{H}), 4.5(\mathrm{~S}, 1 \mathrm{H}$, $\left.\mathrm{H}_{2}\right), 3.9\left(\mathrm{~s}, 3 \mathrm{H}, \mathrm{OCH}_{3}\right), 2.4-3.1\left(\mathrm{~m}, 2 \mathrm{H}, \mathrm{H}_{3}\right)$; UV-Vis (EtOH): 368 (band 1) and 233 (band II) nm.

7b: Molecular formula: $\mathrm{C}_{18} \mathrm{H}_{16} \mathrm{O}_{6}$; yield: $59 \%$; M.P. : 212-214 ${ }^{\circ} \mathrm{C}$; IR (KBr): 1690 (carbonyl acid), 1605 (carbonyl ketone) and 1573 (aromatic) $\mathrm{cm}^{-1}$; ${ }^{\mathrm{H}}$-NMR (DMSO $\left.\mathrm{D}_{6}, 60 \mathrm{MHz}\right)$ : 6.9-7.9 (d, $\left.6 \mathrm{H}, \mathrm{Ar}-\mathrm{H}\right), 4.5(\mathrm{~S}, 1 \mathrm{H}$, $\left.\mathrm{H}_{2}\right), 3.9\left(\mathrm{~s}, 6 \mathrm{H}, \mathrm{OCH}_{3}\right), 2.4-3.0\left(\mathrm{~m}, 2 \mathrm{H}, \mathrm{H}_{3}\right)$; UV-Vis (EtOH): 385 (band 1) and 233 (band II) nm.

\section{RESULT AND DISCUSSION}

In the synthesis of flavanone-6-carboxylic acid via chalcone route, 3-acetyl-4-hydroxybenzoic acid as the acetophenone derivative, and varied benzaldehyde derivatives. There were $p$-anisaldehyde (4-methoxy benzaldehyde) and veratraldehyde (3,4-dimethoxy benzaldehyde) were utilized. Synthesis of the acetophenone was conducted from salicylic derivative, i.e. 4-hydroxy benzoic acid. Sequential esterification towards both carboxylic and phenolic groups produced phenyl ester derivative, i.e. methyl 4-acetoxybenzoate. Solvent-free Fries rearrangement of the ester would give the related acetophenone (Table 1).

The solvent-Fries rearrangement was performed by heating the mixture of methyl 4-acetoxybenzoate, $\mathrm{AlCl}_{3}$ and $\mathrm{KCl}$. The main reactant would melt during the heating, be the reaction media and directly rearranged by Lewis acid. Comparing with previous researches [13] that used toxic solvent as reaction media such as nitrobenzene and chlorobenzene in big amount, this method was more green, simple, convenient and energy-efficient since the rearrangement was performed 
Table 1. Data of conversion of 4-hydroxybenzoic acid into the acetophenone derivative

\begin{tabular}{|c|c|c|c|}
\hline No & Reaction & Reagent & Product \\
\hline 1 & $\begin{array}{l}\text { Esterification of 4- } \\
\text { hydroxybenzoic acid }\end{array}$ & $\mathrm{MeOH}$ and $\mathrm{H}_{2} \mathrm{SO}_{4}$ & $\begin{array}{l}\text { methyl } 4 \text {-hydroxybenzoate, } 87 \% \\
\text { yield and } 100 \% \text { purity. }\end{array}$ \\
\hline 2 & $\begin{array}{l}\text { Acetylation of methyl 4- } \\
\text { hydroxybenzoate }\end{array}$ & $\mathrm{Ac}_{2} \mathrm{O}$ and $\mathrm{H}_{2} \mathrm{SO}_{4}$ & $\begin{array}{l}\text { methyl } 4 \text {-acetoxybenzoate, } 75 \% \\
\text { yield and } 90 \% \text { purity. }\end{array}$ \\
\hline 3 & $\begin{array}{l}\text { Solvent-free Fries } \\
\text { rearrangement of methyl 4- } \\
\text { acetoxybenzoate }\end{array}$ & $\mathrm{AlCl}_{3}$ and $\mathrm{KCl}$ & $\begin{array}{l}3 \text {-acetyl-4-hydroxybenzoic acid, } \\
67 \% \text { yield and } 97 \% \text { purity. }\end{array}$ \\
\hline
\end{tabular}

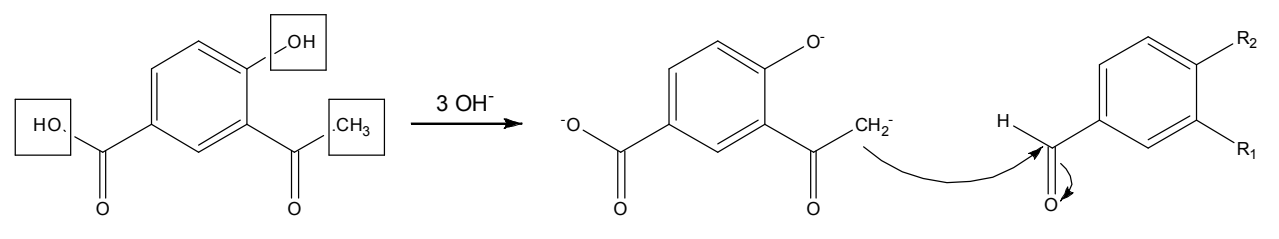

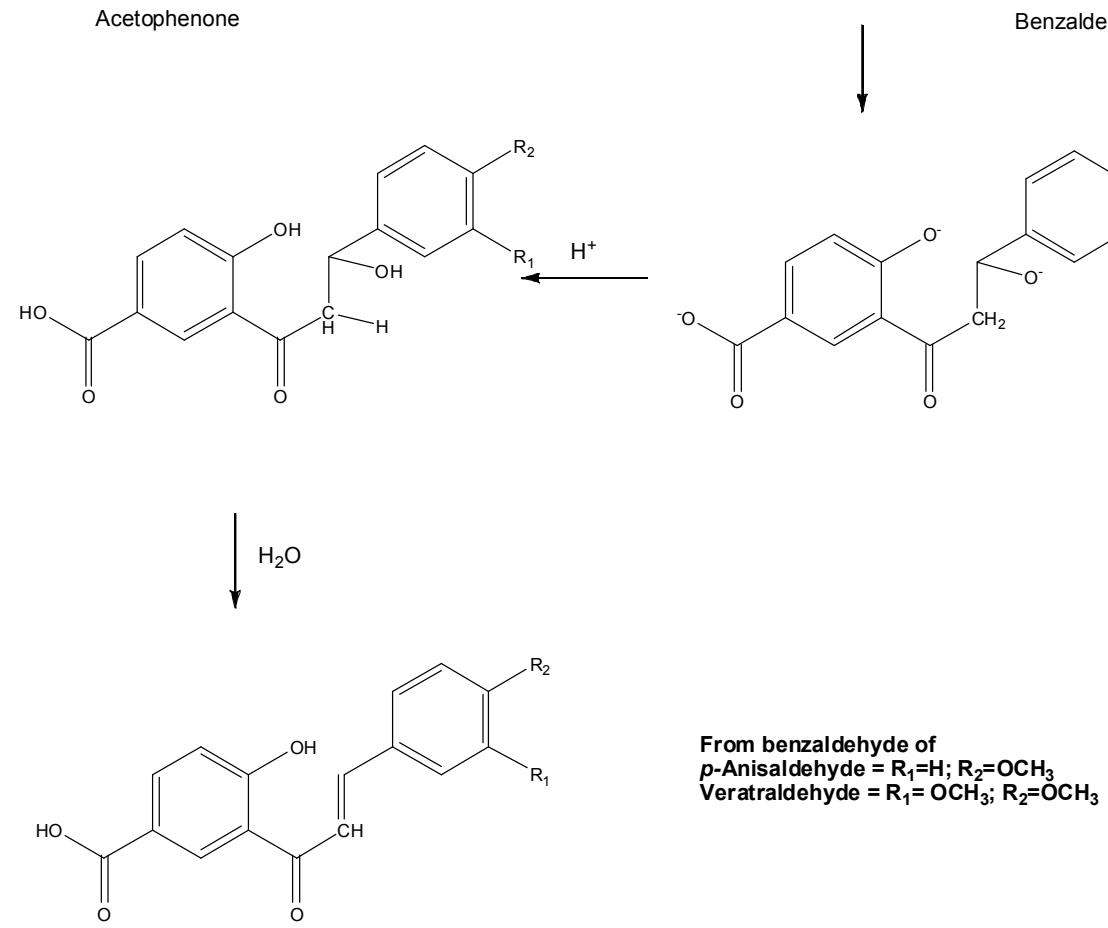

Chalcone-5'-carboxylic acid

Fig 2. Claisen-Schmidt condensation mechanism between the acetophenone and benzaldehyde derivatives

in solvent free condition and used less solvent in the purification of the product. To perform this reaction, 4-hydroxy benzoic acid should be esterified on both its carboxylic and phenolic groups to produce methyl 4-acetoxybenzoate with low melting point $\left(61-67^{\circ} \mathrm{C}\right)$. Phenyl ester of 4-acetoxybenzoic acid (m.p. of $140-141^{\circ} \mathrm{C}$ ) had been also synthesized via esterification just on the phenolic group of 4-hydroxy benzoic acid and conducted the rearrangement towards the phenyl ester. However, this reaction occurred at high temperature as the reactant had high melting point and gave low yield percentage $(5 \%)$.
Next, chalcone derivatives are commonly synthesized via Claisen-Schmidt condensation between benzaldehyde and acetophenone derivatives. This reaction could be catalyzed either by acid or basic catalyst. In acid-catalyzed-condensation, $\mathrm{HCl}, \mathrm{BF}_{3}$, $\mathrm{B}_{2} \mathrm{O}_{3}$, p-toluene sulfonic acid is often employed as the catalyst, where the most common method applies ethanol saturated with $\mathrm{HCl}$ [14]. However, the yield of reaction is relatively low. Therefore, Claisen-Schmidt condensation was carried out under basic condition to obtain chalcone derivatives in this investigation.

In basic condition, three acidic hydrogen of the acetophenone derivative would be ionized. The resulting 
Table 2. Data of synthesis of chalcone-5'-carboxylic acid and flavanone-6-carboxylic acid derivatives.

\begin{tabular}{ccccccc}
\hline Compound & R1 & \multirow{2}{*}{ R2 } & \multicolumn{2}{c}{ Chalcone (6) } & \multicolumn{2}{c}{ Flavanone (7) } \\
\cline { 3 - 6 } & & & Yield (\%) & m.p. $\left({ }^{\circ} \mathrm{C}\right)$ & Yield (\%) & m.p. $\left({ }^{\circ} \mathrm{C}\right)$ \\
\hline a & $\mathrm{H}$ & $\mathrm{OCH}_{3}$ & 81 & $224-226$ & 67 & $209-211$ \\
b & $\mathrm{OCH}_{3}$ & $\mathrm{OCH}_{3}$ & 71 & $226-228$ & 59 & $212-214$ \\
\hline
\end{tabular}

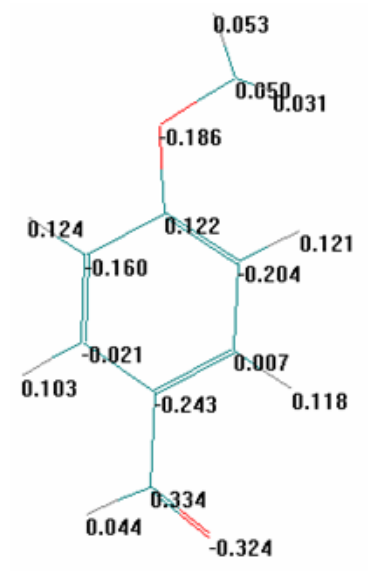

(a)

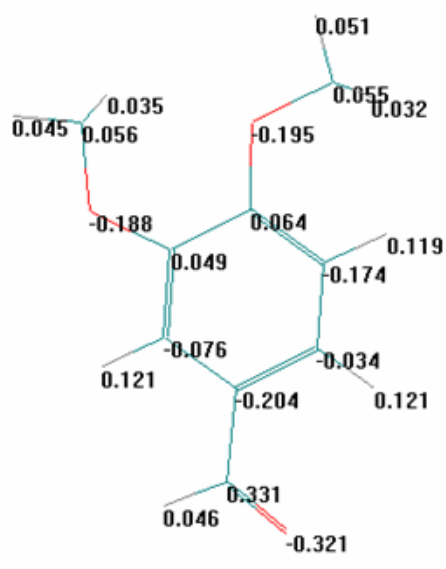

(b)

Fig 3. Calculation of partial charge of: (a) $p$ anisaldehyde and (b) veratraldehyde using Hyperchem 7

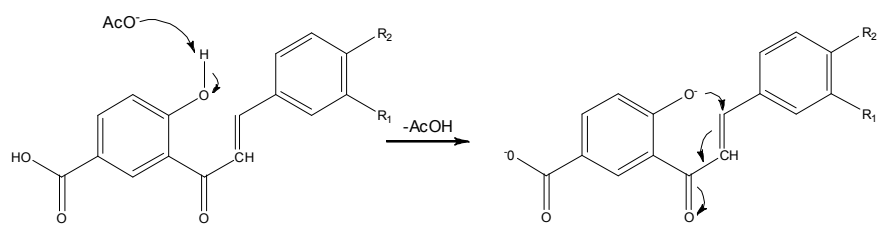

Chalcone Derivative
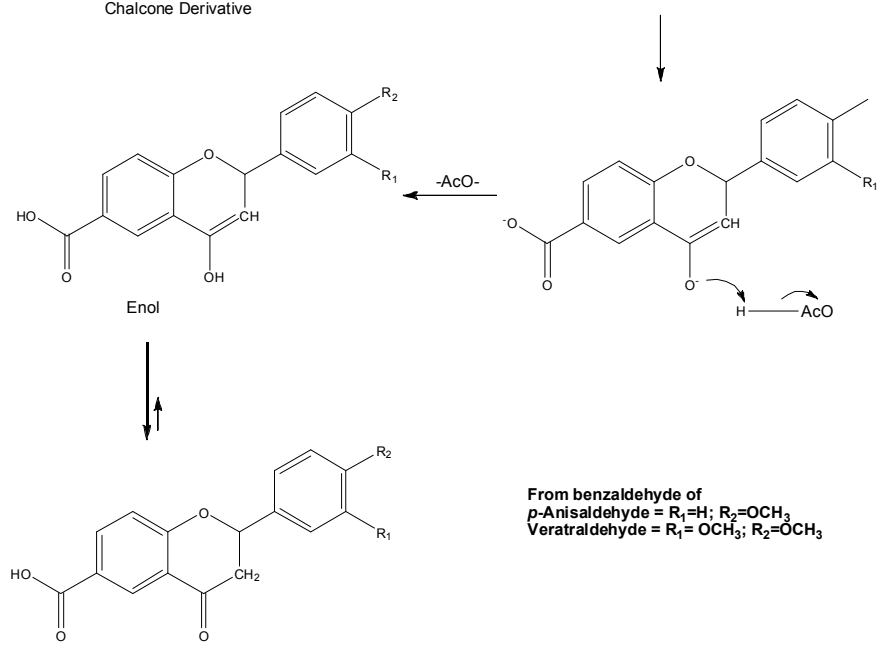

From benzaldehyde of $p$-Anisaldehyde $=\mathrm{R}_{1}=\mathrm{H} ; \mathrm{R}_{2}=\mathrm{OCH}_{3}$
Veratraldehyde $=\mathrm{R}_{1}=\mathrm{OCH}_{3} ; \mathrm{R}_{2}=\mathrm{OCH}_{3}$

Keto, Flavanone-6-carboxylic acid

Fig 4. Reaction Mechanism of Synthesis of Flavanone6-carboxylic acid derivatives

carbanion would then attack the carbonyl group of benzaldehyde derivatives to give tetrahedral intermediate. Finally, the dehydration process would spontaneously occur to finally produce chalcone-5carboxylic acid derivatives (Fig. 2).

As displayed in Table 2, the yield of synthesis of chalcone from $p$-anisaldehyde was higher than from veratraldehyde. This might be explained by evaluating the effect of substituent using a parameter in Hammet equation and calculating the charge of aldehyde carbonyl carbon. There were two reaction sites on this condensation. There was carbanion from the acetophenone and carbonyl carbon from the benzaldehyde. Theoretically, the presence of groups in the benzaldehyde would affect the charge of the carbonyl carbon [15]. In $p$-anisaldehyde, there are one methoxy $\left(\mathrm{OCH}_{3}\right)$ group in para position, with the substituent constant $\sigma_{x}$ of -0.24 , towards the aldehyde carbonyl. The methoxy group, via resonantion effect, might increase the negative charge on the aromatic carbon next to carbonyl carbon and thus, increase the positive charge of the carbonyl carbon. On the other hand, veratraldehyde had 2 methoxy groups in para $\left(\sigma_{x}\right.$ of -0.24$)$ and meta position $\left(\sigma_{x}\right.$ of -0.07$)$. The methoxy group on para position gave the same effect as in $p$-anisaldehyde, while that on meta group had the character of withdrawing group because of induction effect. Thus, it could be indicated that the carbonyl carbon of veratraldehyde was less positive than that of $p$-anisaldehyde. From computational chemistry calculation (Hyperchem 7.0, semi empirical method, PM3), it was known that the charge of carbonyl carbon of $p$-anisaldehyde and veratraldehyde were 0.334 and 0.331 (Fig. 3), respectively. Therefore, it could be said that the meta methoxy group on veratraldehyde did not significantly affect the charge of the reaction site. Additionally, both evaluation of substituent effect and computational calculation supported the result.

Flavanone derivatives is commonly obtained from the corresponding chalcone, via intramolecular 1,4-nucleophilic addition (intramolecular conjugated addition) reaction. This reaction can be performed using acidic or basic as catalyst and heat, microwave as well as light as the energy source $[4,7-8,16-17]$. The acid-catalyzed cyclication can be carried out by refluxing the chalcone in acetic acid or ethanol, in the presence of sulfuric or phosphoric acid. On the other hand, the basic-catalyzed-isomerization can be conducted by refluxing the corresponding chalcone in ethanol with the basic catalyst, such as $\mathrm{NaOAc}$ and KF. In this research, conversion of chalcone into flavanone was conducted in basic condition using $\mathrm{NaOAc}$ catalyst due to the corrosive property of the acid. 


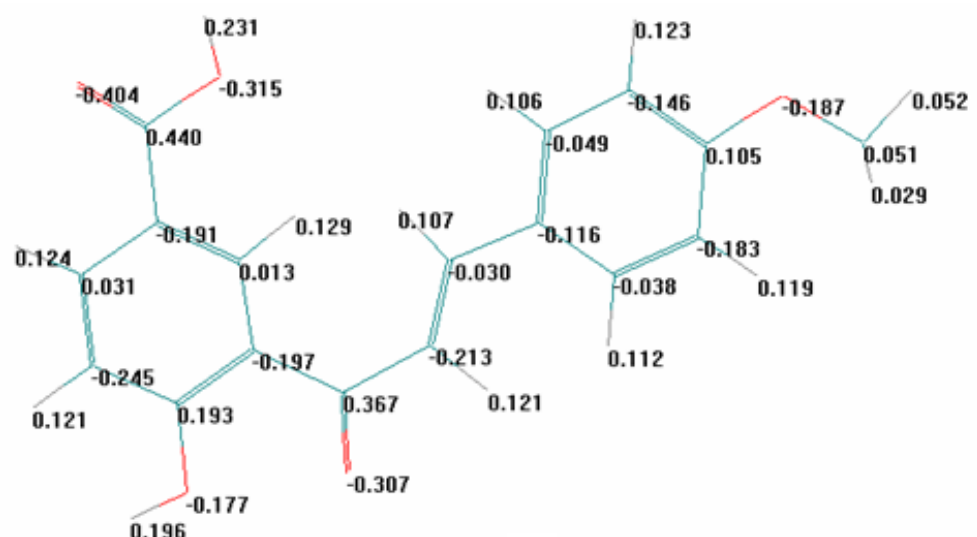

(a)

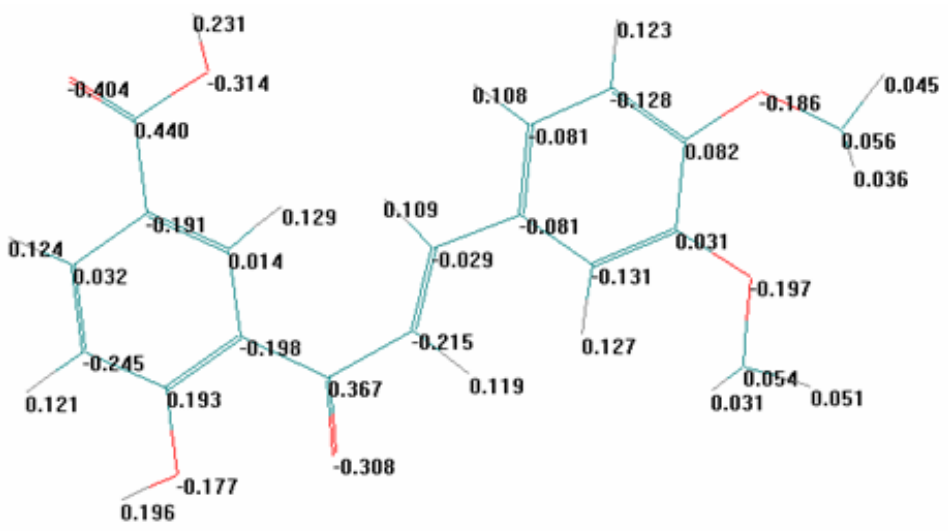

(b)

Fig 5. Calculation of partial charge of chalcone-5'-carboxylic acid from: (a) p-anisaldehyde and (b) veratraldehyde using Hyperchem 7

The conversion of chalcone into flavanone is slow reaction, thus heat or light is needed to accelerate the reaction [17]. Additionally, the heat also might break the hydrogen bond between hydroxy and carbonyl groups. When, the free phenolic group was formed, acetate ion $\left(\mathrm{AcO}^{-}\right)$attacked its proton to yield the phenoxide as the nucleophile. The resulted nucleophile then attacked the conjugated double bond to yield the enol form of flavanone. Since the keto form was more stable than the enol, the former will be readily formed and yield flavanone-6-carboxylic acid (Fig. 4).

The reaction sites of this intramolecular cyclication reaction were phenoxide as the nucleophile and conjugated double bond as the electrophile. The methoxy groups on the ring $B$ tended to affect the charge of conjugated double bond with the same manner as explained before. Based on computational calculation, the charges of conjugated double bond of chalcone A and B were -0.030 and -0.029 , respectively (Fig. 5). Therefore, both evaluation of substituent effect and computational calculation supported the result.

For further work, the biological assay of the synthesized chalcones and flavanones would be performed. The activity of the compounds as anti malaria agent against Plasmodium falciparum FCR 3 will be tested.

\section{CONCLUSION}

Flavonoid of flavanone-6-carboxylic acid derivatives could be synthesized from the key compounds of the acetophenone of 3-acetyl-4hydroxybenzoic acid and the benzaldehyde derivatives of $p$-anisaldehyde and veratraldehyde. The acetophenone was obtained from salicylic acid via esterification on both phenolic and carboxylic groups. Claisen-Schmidt condensation of the acetophenone and benzaldehyde derivatives of $p$-anisaldehyde and veratraldehyde in basic condition gave 2'hydroxychalcone-5'-carboxylic acid derivatives in 81 and $71 \%$ yield, respectively. The isomerization of the chalcone under basic condition yielded the corresponding flavanone-6-carboxylic acids in 67 and $59 \%$ yield, respectively. 


\section{REFERENCES}

1. Hsiao, C.Y., Kuo, H.W., Chen, N.P., Chang, R.H., Lin, H.T., Yang, E.W., Hsieh, S.Y., and Chu, C.S., 2007, Chem. Biol. Interact., 167, 3, 193-206.

2. Zhang, B., Ye., X., Chen, Z., Jiang, X., Yuan, L., Yi, J. and Li, X., 2010, Med. Chem. Res., 10, 9462.

3. Chandrasekhar, S., Vijeender, K., and Reddy, K.V., 2005, Tetrahedron Lett., 46, 41, 6991-6993.

4. Pouget, C., Fagnere, C., Basly, J.P., Besson, A.E., Champavier, Y., Habrioux, G., and Chulia, A.J., 2002, Pharm. Res., 19, 3, 286-291.

5. Peterson, J.J., Dwyer, J.T., Beecher, G.R., Bhagwat, S.A., Gebhardt, S.E., Haytowitz, D.B., and Holden, J.M., 2006, J. Food Compos. Anal., 19, S66-S73.

6. Peterson, J.J., Beecher, G.R., Bhagwat, S.A., Dwyer, J.T., Gebhardt, S.E., Haytowitz, D.B., and Holden, J.M., 2006, J. Food Compos. Anal., 19, S74-S80.

7. Ismiyarto, 2000, Sintesis Senyawa Kalkon Dan Flavanon Menggunakan Bahan Dasar Senyawa Turunan Asetofenon Dan Benzaldehida, Thesis, Graduate Program UGM, Yogyakarta.

8. Handayani, S, 2000, Sintesis 4'-Metoksiflavanon Menggunakan o-Hidroksiasetofenon Dan pAnisaldehida Dari Minyak Adas, Thesis, Graduate Program UGM, Yogyakarta.
9. Begum, N.A., Roy, N., Laskar, R.A., and Roy, K., 2010, Med. Chem. Res., 20, 2, 184-191.

10. Mardjan, M.I.D., Matsjeh, S., and Wahyuningsih, T.D., 2010, Synthesis of Flavanone-6-carboxylic acid, Proceeding of The $2^{\text {nd }}$ International Conference on Chemical Sciences 2010, Conducted in Yogyakarta October 2010.

11. Kusumaningsih, T., Sastrohamidjojo, H., and Soelistyowati, R., 2000, Teknosains, 13, 2, 247-261.

12. Wahyuningsih, T.D., Raharjo, T.J., Tahir, I., and Noegrohati, S., 2002, Indo. J. Chem., 2, 1, 55-63.

13. Qi-meng, R., and Jia-you, S., 2004, Fries Rearrangement: A New Practical Synthesis of 4,4'dihydroxybenzophenine (I), Wuhai University, Hubei.

14. Patil, C.B., Mahajan, S.K., and Katti, A., 2009. J. Pharm. Sci. Res., 1, 3, 11-22.

15. Anslyn, E.V., and Dougherty, D.A., 2006, Modern Physical Organic Chemistry, University Science Books, Sausalito.

16. Choi, Y.J., Kim, H.M., and Kim, H.D., 2009, Arch. Pharm. Res., 32, 1, 59-63.

17. Sagrera, G.J., and Seoane, G.A., 2005, J. Braz. Chem. Soc., 16, 4, 851-856. 